\title{
Assessment of enamel demineralization using conventional, digital, and digitized radiography
}

\section{Avaliação da desmineralização do esmalte por meio de radiografias convencional, digital e digitalizada}

\author{
Rivea Inês Ferreira* \\ Francisco Haiter-Neto** \\ Cinthia Pereira Machado Tabchoury*** \\ Guilherme Assumpção Neves de Paiva**** \\ Frab Norberto Bóscolo*****
}

\begin{abstract}
This experimental research aimed at evaluating the accuracy of enamel demineralization detection using conventional, digital, and digitized radiographs, as well as to compare radiographs and logarithmically contrast-enhanced subtraction images. Enamel subsurface demineralization was induced on one of the approximal surfaces of 49 sound third molars. Standardized radiographs of the teeth were taken prior to and after the demineralization phase with three digital systems - CygnusRay MPS ${ }^{\circledR}$, DenOptix ${ }^{\circledR}$ and DIGORA ${ }^{\circledR}$ - and InSight ${ }^{\circledR}$ film. Three radiologists interpreted the pairs of conventional, digital, and digitized radiographs in two different occasions. Logarithmically contrast-enhanced subtraction images were examined by a fourth radiologist only once. Radiographic diagnosis was validated by cross-sectional microhardness profiling in the test areas of the approximal surfaces. Accuracy was estimated by Receiver Operating Characteristic (ROC) analysis. Chi-square test, at a significance level of $5 \%$, was used to compare the areas under the ROC curves $\left(\mathrm{A}_{z}\right)$ calculated for the different imaging modalities. Concerning the radiographs, the DenOptix ${ }^{\circledR}$ system $\left(A_{z}=0.91\right)$ and conventional radiographs $\left(A_{z}=0.90\right)$ presented the highest accuracy values compared with the other three radiographic modalities. However, logarithmically contrast-enhanced subtraction images $\left(\mathrm{A}_{\mathrm{z}}=0.98\right)$ were significantly more accurate than conventional, digital, and digitized radiographs $(p=0.0000)$. It can be concluded that the DenOptix ${ }^{\circledast}$ system and conventional radiographs provide better performance for diagnosing enamel subsurface demineralization. Logarithmic subtraction significantly improves radiographic detection.
\end{abstract}

DESCRIPTORS: Dental enamel; Demineralization; Radiography; Diagnosis.

\begin{abstract}
RESUMO: O objetivo desta pesquisa experimental foi investigar a acurácia da detecção de desmineralizações em esmalte por meio de radiografias convencionais, digitais e digitalizadas, e compará-las às imagens por subtração logarítmica. Foram induzidas desmineralizações subsuperficiais no esmalte de uma das faces proximais de 49 dentes terceiros molares hígidos. Radiografias padronizadas dos dentes foram obtidas antes e após a fase de desmineralização com o emprego de três sistemas digitais - CygnusRay MPS ${ }^{\circledR}$, DenOptix ${ }^{\circledR}$ e DIGORA $^{\circledR}$ - bem como do filme InSight ${ }^{\circledast}$. Três radiologistas interpretaram os pares de radiografias convencionais, digitais e digitalizadas, em duas ocasiões diferentes. As imagens por subtração logarítmica foram avaliadas por um quarto radiologista apenas uma vez. O diagnóstico radiográfico foi validado pela mensuração da microdureza do esmalte seccionado longitudinalmente, nas áreas-teste das faces proximais. A acurácia foi estimada pela análise "Receiver Operating Characteristic" (ROC). Aplicou-se o teste Qui-Quadrado, em um nível de significância de 5\%, para comparar as áreas sob as curvas ROC $\left(\mathrm{A}_{2}\right)$ das diferentes modalidades de imagens radiográficas. Em se tratando das radiografias, o sistema DenOptix ${ }^{\circledR}\left(A_{z}=0,91\right)$ e as radiografias convencionais $\left(A_{z}=0,90\right)$ apresentaram os maiores valores de acurácia em relação às outras três modalidades de imagem. No entanto, as imagens por subtração logarítmica $\left(\mathrm{A}_{\mathrm{z}}=0,98\right)$ superaram as radiografias convencionais, digitais e digitalizadas $(p=0,0000)$. Conclui-se que o sistema DenOptix $^{\circledast}$ e as radiografias convencionais demonstram melhor desempenho no diagnóstico das desmineralizações subsuperficiais em esmalte. A subtração logarítmica aprimora significativamente a detecção radiográfica.
\end{abstract}

DESCRITORES: Esmalte dentário; Desmineralização; Radiografia; Diagnóstico.

\footnotetext{
* Associate Professor; ${ }^{* * *}$ Research Fellow - Department of Pediatric Dentistry and Orthodontics, São Paulo City University.

** Associate Professor, Department of Oral Diagnosis; ***Associate Professor, Department of Physiological Sciences; *****Professor, Chairman, Department of Oral Diagnosis - School of Dentistry of Piracicaba, State University of Campinas.
} 
Ferreira RI, Haiter-Neto F, Tabchoury CPM, Paiva GAN, Bóscolo FN. Assessment of enamel demineralization using conventional, digital, and digitized radiography. Braz Oral Res 2006;20(2):114-9.

\section{INTRODUCTION}

Even with the benefit of radiographs, it is recognized that the diagnosis of approximal enamel caries lesions is an inherently difficult task, since demineralization in excess of $40 \%$ must occur for the radiographic detection to be possible ${ }^{12}$. This limitation of radiographic detection encourages studies that compare the diagnostic accuracy of different imaging systems and the search for improved image processing techniques ${ }^{18}$.

Currently, there are several commercially available digital radiographic systems as alternatives to conventional radiography. At the same time, one of the most commonly used digital processing techniques involves the subtraction of one image from another ${ }^{3}$. Two digital or digitized radiographs are taken over a period of time and the resultant matrices of numbers, with pixel values varying from zero to 255 , are mathematically subtracted from each other ${ }^{3,5,13,17}$.

Thus, the purpose of the present investigation was to evaluate the diagnostic accuracy of conventional, digital, and digitized radiographs for detecting approximal enamel caries-like lesions. In addition, radiography was compared with logarithmic subtraction in the diagnosis of enamel subsurface demineralization. The null hypothesis stated no differences in performance between the studied imaging modalities.

\section{MATERIALS AND METHODS}

This experimental research is in agreement with Resolution 196/96 from the National Committee of Health/Health Department (Brazil).

\section{Experimental design}

Forty-nine caries-free human third molars were randomly collected and two amalgam restorations were made on the lingual surface of each tooth to be used as reference points during the alignment of successive radiographs. The crowns were covered with acid-resistant varnish, except for a circular window of about $7 \mathrm{~mm}^{2}$ on one of the approximal surfaces. The experimental teeth were kept individually immersed in demineralizing solution at $37^{\circ} \mathrm{C}$ for 120 days ${ }^{1,5}$.

Standardized radiographs of the teeth were taken prior to and after the demineralization period. A $2.5 \mathrm{~cm}$ thick acrylic plate was positioned in front of the teeth to simulate the soft tissues. The teeth were radiographed using a GE $1000^{\circledR}$ X-ray unit (General Electric Co., Milwaukee, USA), operating at $70 \mathrm{kVp}, 10 \mathrm{~mA}, 2.5 \mathrm{~mm}$ total aluminum filtration, and a $40 \mathrm{~cm}$ focus-receptor distance. The radiographs were taken with four different image receptors: film (InSight ${ }^{\circledR}$; Eastman Kodak Co., Rochester, USA), a charge-coupled device sensor (CygnusRay MPS ${ }^{\circledR}$; Cygnus Technologies, Scottsdale, USA), and two photostimulable phosphor plates (DenOptix ${ }^{\circledR}$; Dentsply International/Gendex ${ }^{\circledR}$ Dental X-ray Division, Des Plaines, USA; and DIGORA ${ }^{\circledR}$, white plates, Orion Corp./Soredex ${ }^{\circledR}$, Helsinki, Finland). The exposure times selected for the solidstate sensor and the two photostimulable phosphor plates were 0.13 and 0.16 seconds, respectively. Films were exposed using 0.3 seconds.

The DenOptix ${ }^{\circledR}$ plates were scanned at a resolution of 300 dpi. Films were processed in a dark room under a red safelight (GBX II; Eastman Kodak Co.) using fresh Readymatic ${ }^{\circledR}$ processing solutions (Eastman Kodak Co.) in an automatic processor (GXP ${ }^{\circledR}$; Dentsply International/Gendex ${ }^{\circledR}$ Dental Xray Division). Conventional radiographs were digitized by means of a laser scanner (ScanJet 4C/T ${ }^{\circledR}$; Hewlett Packard Co., Greeley, USA) and processed using the Adobe Photoshop ${ }^{\circledR} 5.0$ software (Adobe Systems Incorporated, San Jose, USA) in gray scale mode with a resolution of $300 \mathrm{dpi}$ and stored as 8-bit TIFF images.

Direct and indirect digital subtraction techniques were performed using the $\mathrm{EMAGO}^{\circledR} / \mathrm{Ad}-$ vanced 3.43 software (Oral Diagnostic Systems, Amsterdam, The Netherlands). After gamma correction and any necessary reconstructions, the "logarithmic subtraction" command generated the subtraction images. Reconstruction involves the production of a final radiograph according to the exposure geometry of the reference radiograph. This procedure was necessary because, although an acrylic device enabled the acquisition of standardized radiographs, there were some pairs of radiographs with geometric discrepancy.

\section{Radiographic interpretation}

A panel of three oral and maxillofacial radiologists independently examined the pairs of conventional, digital, and digitized radiographs. Following a calibration session, the observers were instructed to compare the reference and the final radiographs and score the approximal surfaces in the final radiograph using a five-point confidence rating scale:

1. enamel subsurface demineralization definitely absent; 
Ferreira RI, Haiter-Neto F, Tabchoury CPM, Paiva GAN, Bóscolo FN. Assessment of enamel demineralization using conventional, digital, and digitized radiography. Braz Oral Res 2006;20(2):114-9.

2. enamel subsurface demineralization probably absent;

3. unsure if enamel subsurface demineralization is present or absent;

4. enamel subsurface demineralization probably present;

5. enamel subsurface demineralization definitely present.

Digital and digitized radiographs were presented in random order on an SVGA 15-inch monitor screen. Only one pair of radiographs was displayed at a time and all viewing was performed under uniform subdued lighting in a quiet, secluded room. The analog brightness and contrast controls on the monitor were kept constant during the assessments. Digital and digitized radiographs were imported into the EMAGO ${ }^{\circledR} /$ Advanced 3.43 program and the observers were asked to use the software's brightness and contrast commands to manipulate image characteristics intuitively to better extract the signal of interest, as well as to apply

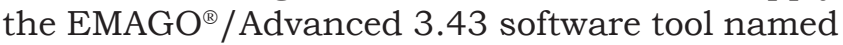
"zoom 1:1". This tool enables the observer to view the images at a two-times magnification.

Conventional radiographs, mounted in pairs, were examined using a viewing box with constant light intensity and a two-times magnification Xviewer, Viewscope ${ }^{\circledR}$ (Flow X-ray Corp., West Hempstead, USA). The interpretations of the conventional radiographs were performed under uniform subdued lighting in the same quiet, secluded room.

All 490 scorings (98 approximal surfaces, five radiographic modalities - conventional, digitized, and digital radiographs acquired with CygnusRay MPS $^{\circledR}$, DenOptix $^{\circledR}$ and DIGORA ${ }^{\circledR}$ ) were performed twice by each observer. A period of at least two weeks was allowed to elapse between the first and second interpretation sessions. A fourth oral and maxillofacial radiologist assessed a total of $196 \mathrm{log}-$ arithmically contrast-enhanced subtraction images (49 teeth, four radiographic modalities - digitized and digital radiographs acquired with CygnusRay MPS $^{\circledast}$, DenOptix ${ }^{\circledR}$ and DIGORA ${ }^{\circledR}$ ) according to the conditions described above. The subtraction images were examined only once.

\section{Validation}

For the validation of the true absence or presence of approximal enamel subsurface demineralization and to measure the depth of demineralization, the enamel test areas were submitted to cross-sectional microhardness profiling ${ }^{1}$. One independent, calibrated and well-trained operator carried out the microhardness measurements.

\section{Statistical analysis}

Receiver Operating Characteristic (ROC) analysis was used to assess the observers' performance in detecting approximal enamel subsurface demineralization with conventional, digital, and digitized radiographs. Using the STATA ${ }^{\circledR} 7.0$ package (StataCorp LP, College Station, USA), ROC curves were generated for each combination of observer (3), modality (5) and interpretation session (2). For the subtraction images, the scorings were classified into a so-called decision matrix and also treated according to the ROC method.

The areas under the ROC curves, designated as $A_{z}$, represent the efficiency of the diagnostic method and were used as indices of accuracy. Differences between the $A_{z}$ values were tested using the chi-square test. The level of significance was set at $p=0.05$.

\section{RESULTS}

Table 1 shows the performance of observers using conventional, digital, and digitized radiographs for detecting approximal demineralization limited to the enamel layer. Chi-square statistics indicated significant differences among the five radiographic modalities. Consequently, pair-wise comparisons were carried out between them.

There were statistically significant differences between the radiographs acquired with CygnusRay MPS $^{\circledast}$ and DenOptix ${ }^{\circledR}[$ Chi2(1) $=5.93, p=0.0149]$, as well as between CygnusRay MPS ${ }^{\circledR}$ and conventional radiography [Chi2 $(1)=4.99, p=0.0255]$.

TABLE $1-A_{z}$ values for detecting enamel subsurface demineralization with conventional, digital, and digitized radiographs.

\begin{tabular}{l|c|c|c}
\hline \hline \multicolumn{1}{c|}{ Modality } & $\mathrm{A}_{z}$ & $\begin{array}{c}\text { Standard } \\
\text { Deviation }\end{array}$ & $\begin{array}{c}95 \% \text { Confidence } \\
\text { Interval }\end{array}$ \\
\hline $\begin{array}{l}\text { CygnusRay } \\
\text { MPS }^{\circledR}\end{array}$ & 0.85 & 0.0244 & $0.80147-0.89727$ \\
\hline DenOptix $^{\circledR}$ & 0.91 & 0.0190 & $0.86876-0.94332$ \\
\hline DIGORA $^{\circledR}$ & 0.89 & 0.0207 & $0.84799-0.92896$ \\
\hline $\begin{array}{l}\text { Conventional } \\
\text { radiography }\end{array}$ & 0.90 & 0.0203 & $0.86075-0.94052$ \\
\hline $\begin{array}{l}\text { Digitized } \\
\text { radiography }\end{array}$ & 0.84 & 0.0243 & $0.79284-0.88810$ \\
\hline \hline
\end{tabular}

Chi2(4) $=10.77, p=0.0292$. 
Ferreira RI, Haiter-Neto F, Tabchoury CPM, Paiva GAN, Bóscolo FN. Assessment of enamel demineralization using conventional, digital, and digitized radiography. Braz Oral Res 2006;20(2):114-9.

When comparing digital and digitized radiographs, the chi-square test demonstrated a significant difference only between DenOptix ${ }^{\circledR}$ and digitized radiography [Chi2(1) $=6.33, p=0.0118]$. In addition, the $A_{z}$ value calculated for conventional radiography was significantly higher in comparison with digitized radiography $[\mathrm{Chi} 2(1)=7.35, p=0.0067$. No significant differences were found in the other pair-wise comparisons.

In Figure 1, pairs of digital and digitized radiographs are shown. The final radiographs depicted the changes in radiographic density within the approximal enamel layer on the right side, in a tooth that remained immersed in demineralizing solution for a period of 120 days.
No significant differences were found between logarithmically contrast-enhanced subtraction images produced with digital and digitized radiographs $[\mathrm{Chi} 2(3)=3.17, p=0.3657$. For a comparison of the six studied imaging modalities, data obtained for all subtraction images were pooled and submitted to ROC analysis and chi-square test. The resultant $A_{z}$ value for logarithmic subtraction was significantly higher in relation to conventional, digital, and digitized radiography. Tables 2 and 3 illustrate the comparisons between logarithmic subtraction and the radiographic modalities with the highest $A_{z}$ values - DenOptix ${ }^{\circledR}$ and conventional radiography, respectively.

Figure 2 shows logarithmically contrast-enhanced subtraction images produced with the

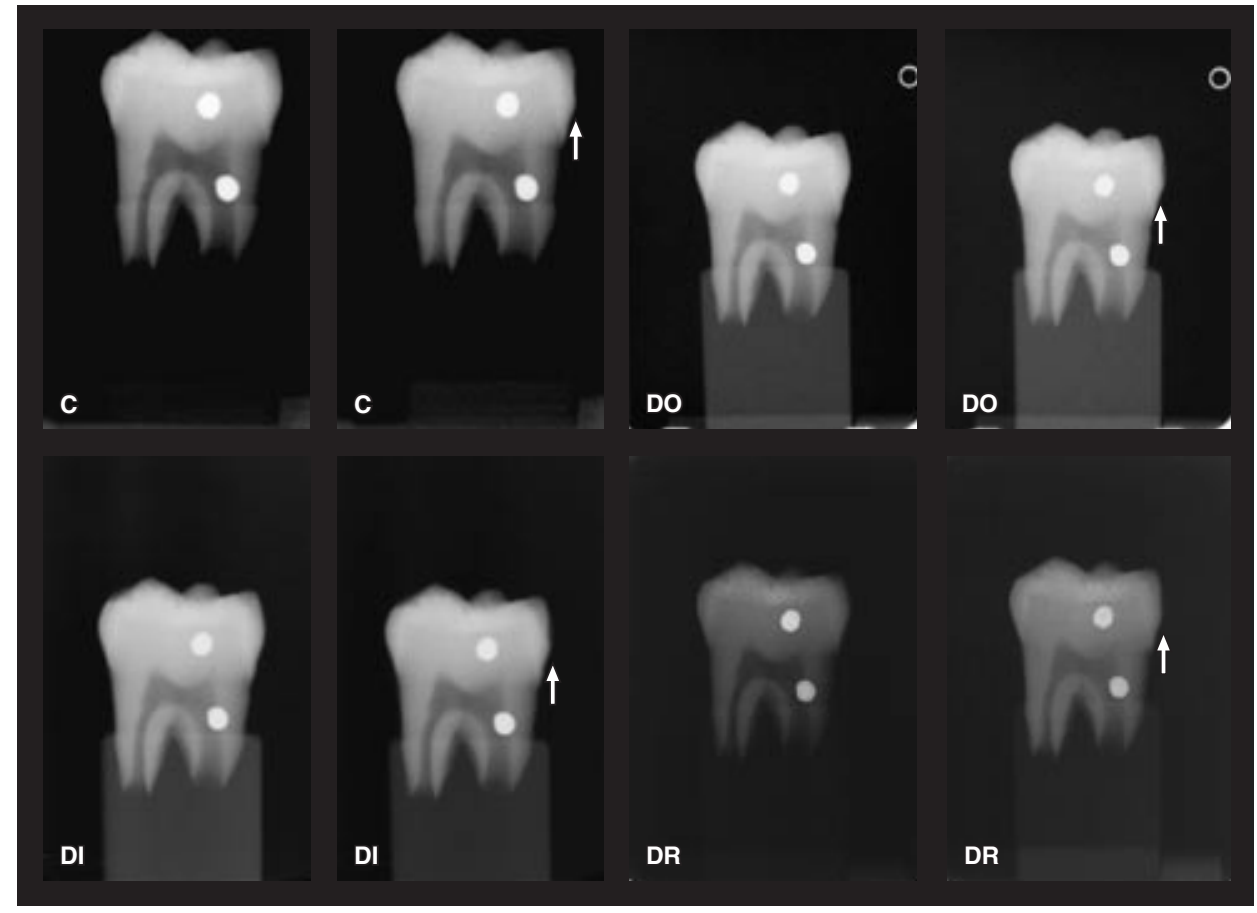

FIGURE 1 - Radiographic images acquired with CygnusRay MPS $^{\circledast}$ (C), DenOptix ${ }^{\circledast}$ (DO) and DIGORA $^{\circledR}(\mathbf{D I})$, and digitized radiographs (DR), before and after the demineralization period. The arrow indicates the approximal surface of a tooth immersed in demineralizing solution for 120 days, which presents an artificial enamel subsurface demineralization.

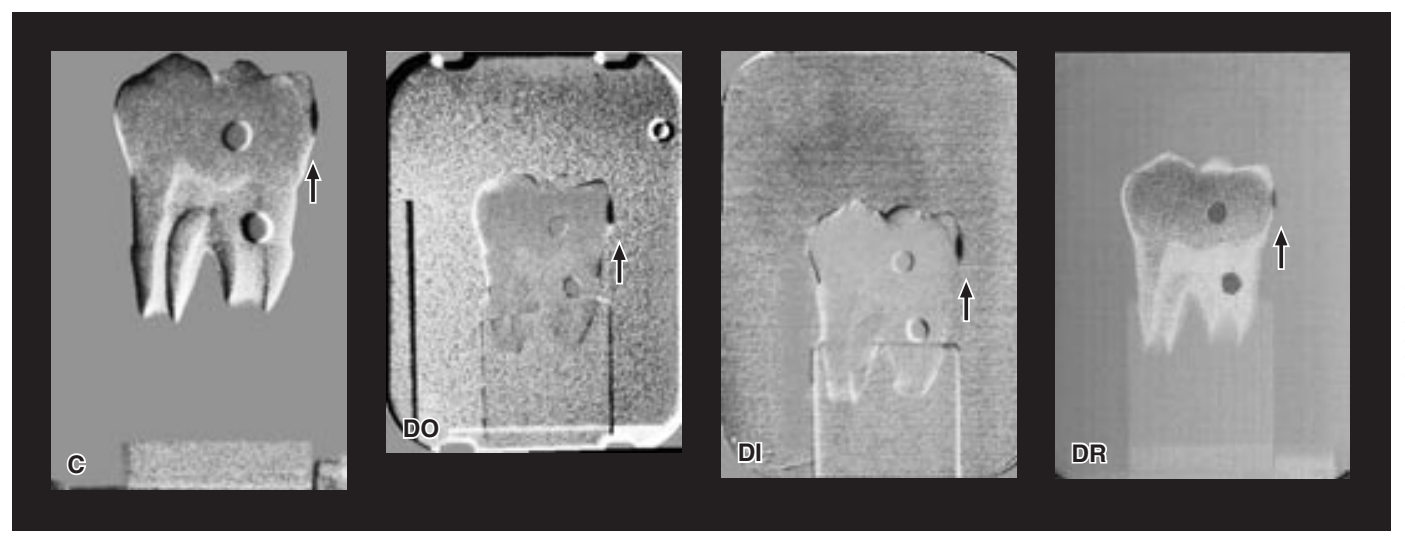

FIGURE 2 -

Logarithmically contrast-enhanced subtraction images produced with the pairs of radiographs presented in Figure 1. C, CygnusRay MPS ${ }^{\circledR}$. DO, DenOptix ${ }^{\circledR}$. DI, DIGORA $^{\circledR}$. DR, Digitized radiograph. 
Ferreira RI, Haiter-Neto F, Tabchoury CPM, Paiva GAN, Bóscolo FN. Assessment of enamel demineralization using conventional, digital, and digitized radiography. Braz Oral Res 2006;20(2):114-9.

TABLE 2 - Comparison of the diagnostic accuracy, expressed as $\mathrm{A}_{z}$, between DenOptix ${ }^{\circledR}$ images and subtraction images.

\begin{tabular}{c|c|c|c}
\hline \hline Modality & $\mathrm{A}_{z}$ & $\begin{array}{c}\text { Standard } \\
\text { Deviation }\end{array}$ & $\begin{array}{c}95 \% \text { Confidence } \\
\text { Interval }\end{array}$ \\
\hline DenOptix $^{\circledR}$ & 0.91 & 0.0190 & $0.86876-0.94332$ \\
\hline Subtraction & 0.98 & 0.0066 & $0.97182-0.99777$ \\
\hline \hline
\end{tabular}

Chi2(1) $=19.68, p=0.0000$.

pairs of radiographs presented in Figure 1. These images clearly reveal density decrease on the right approximal surface of the tooth.

Microscopic examination of the experimental teeth showed that the approximal enamel outer surfaces in the test areas were not disrupted. The minimum estimated demineralization depth was around $230 \mu \mathrm{m}$, and the maximum estimated demineralization depth was beyond $410 \mu \mathrm{m}$ inward the enamel layer. The degree of mineral loss was not uniform in the total sample of teeth, as subsurface demineralization is related to individual characteristics of the teeth, such as the fluoride content and the amount of carbonated hydroxyapatite of the substrate enamel in the test area ${ }^{2}$.

\section{DISCUSSION}

Considering that radiography is the most feasible method for detecting approximal caries lesions and the clinical use of digital subtraction is limited by the reproducibility of exposure geometry ${ }^{3,5,17}$, it would be justifiable to compare the diagnostic accuracy of radiographs acquired with different image receptors. In this in vitro study, logarithmic subtraction was used as an alternative technique for comparison.

In terms of the diagnostic accuracy for approximal enamel subsurface demineralization detection, no significant differences between the storage phosphor systems and conventional radiography were demonstrated. Our findings are in accordance with the results of previous studies, in which the DIGORA $^{\circledR}$ system was compared with film ${ }^{7-9,14,15}$. Since there was no significant difference between DenOptix $^{\circledR}$ and DIGORA ${ }^{\circledR}$, it may be suggested that both storage phosphor systems perform similarly. Hintze et al. ${ }^{6}$ (2002) also reported no significant difference in accuracy between DenOptix ${ }^{\circledR}$ and DIGORA $^{\circledR}$, but only when an increased exposure time was used, i.e. $25 \%$ of that selected for Ektaspeed Plus ${ }^{\circledR}$ film. It should be noted that, in the present study, the exposure selected for the two pho-
TABLE 3 - Comparison of the diagnostic accuracy, expressed as $A_{z}$, between conventional radiographs and subtraction images.

\begin{tabular}{c|c|c|c}
\hline \hline Modality & $\mathrm{A}_{z}$ & $\begin{array}{c}\text { Standard } \\
\text { Deviation }\end{array}$ & $\begin{array}{c}95 \% \text { Confidence } \\
\text { Interval }\end{array}$ \\
\hline $\begin{array}{l}\text { Conventional } \\
\text { radiography }\end{array}$ & 0.90 & 0.0203 & $0.86075-0.94052$ \\
\hline Subtraction & 0.98 & 0.0066 & $0.97182-0.99777$ \\
\hline \hline
\end{tabular}

Chi2(1) $=18.03, p=0.0000$.

tostimulable phosphor plates was approximately $53 \%$ of that used for Insight ${ }^{\circledR}$ film.

CygnusRay MPS ${ }^{\circledR}$ and other CCD-based systems use the same basic technology for capturing and displaying the radiographic information. Hence, it would be reasonable to assume that CygnusRay MPS ${ }^{\circledR}$ may reach a diagnostic accuracy level consistent with the performance reported for the CCD-based systems. No significant difference was found between CygnusRay MPS ${ }^{\circledR}$ and DIGO$\mathrm{RA}^{\circledR}$. When comparing CCD-based systems with DIGORA $^{\circledR}$, Haak et al. ${ }^{4}$ (2001), Syriopoulos et al. ${ }^{15}$ (2000) and Wenzel et al. ${ }^{16}$ (1995) also did not find statistically significant differences as far as the diagnostic performance is concerned. However, Price, Ergül $1^{11}$ (1997) reported that the CCD-based system was significantly inferior to film.

Regarding the comparisons between CCDbased and storage phosphor systems, the radiographic images acquired with DenOptix ${ }^{\circledR}$ provided a significantly better diagnostic accuracy than the CygnusRay MPS ${ }^{\circledR}$ images. Thus, it can be suggested that storage phosphor systems may be at least comparable, or even superior, to CCD-based systems for detecting incipient approximal caries lesions.

Theoretically, for digital images, the resolution power is a function of pixel size, and the small pixel size of CCD-based radiographic images should result in better image quality, as it has already been discussed by other authors ${ }^{8,14}$. It is also known that, as the pixel size decreases, the noise level relative to the signal increases ${ }^{14}$. A combination of a wide exposure range and sufficient pixel size may have accounted for the favorable diagnostic performance obtained with the storage phosphor systems in this study. Presumably, noise and spatial resolution were balanced.

The smallest area under the ROC curves corresponded to the diagnostic performance with digitized radiographs. Not surprisingly, digitized radiography was significantly inferior compared with conventional radiography ${ }^{3,10}$. The demands for radiographic image sharpness are greater during the 
Ferreira RI, Haiter-Neto F, Tabchoury CPM, Paiva GAN, Bóscolo FN. Assessment of enamel demineralization using conventional, digital, and digitized radiography. Braz Oral Res 2006;20(2):114-9.

diagnosis of enamel subsurface demineralization, which in turn highlight the differences between conventional and digitized radiographs. Besides, the process of digitization has been demonstrated to add physical noise to the radiographic image ${ }^{8,17}$. Noise is an important factor when determining image quality, and it may have an impact on the conspicuousness of small caries lesions ${ }^{6}$.

Logarithmically contrast-enhanced subtraction images performed consistently better than radiographs whatever the imaging modality used. In spite of the low $\mathrm{A}_{z}$ values calculated for the CygnusRay MPS ${ }^{\circledR}$ and digitized radiographs, digital subtraction improved the diagnostic accuracy with radiographic images in which the noise level was high. Employing digital subtraction, all four imaging modalities studied - digitized radiography, CygnusRay MPS ${ }^{\circledR}$, DenOptix ${ }^{\circledR}$, and DIGORA ${ }^{\circledR}$ - performed equally. In contrast, significant differences between logarithmically contrast-enhanced subtraction images and conventional, digital and digi-

\section{REFERENCES}

1. Argenta RMO, Tabchoury CPM, Cury JA. A modified pHcycling model to evaluate fluoride effect on enamel demineralization. Pesqui Odontol Bras 2003;17(3):241-6.

2. Boyle EL, Higham SM, Edgar WM. The production of subsurface artificial caries lesions on third molar teeth. Caries Res 1998;32(2):154-8.

3. Dove SB, McDavid WD. A comparison of conventional intraoral radiography and computer imaging techniques for the detection of proximal surface dental caries. Dentomaxillofac Radiol 1992;21(3):127-34.

4. Haak R, Wicht MJ, Noack MJ. Conventional, digital and contrast-enhanced bitewing radiographs in the decision to restore approximal carious lesions. Caries Res 2001;35(3):193-9.

5. Haiter-Neto F, Ferreira RI, Tabchoury CPM, Bóscolo FN. Linear and logarithmic subtraction for detecting enamel subsurface demineralization. Dentomaxillofac Radiol 2005;34(3):133-9.

6. Hintze H, Wenzel A, Frydenberg M. Accuracy of caries detection with four storage phosphor systems and E-speed radiographs. Dentomaxillofac Radiol 2002;31(3):170-5.

7. Matsuda Y, Okano T, Igeta A, Seki K. Effects of exposure reduction on the accuracy of an intraoral photostimulablephosphor imaging system in detecting incipient proximal caries. Oral Radiol 1995;11(1):11-6.

8. Moystad A, Svanaes DB, Risnes S, Larheim TA, Gröndahl HG. Detection of approximal caries with a storage phosphor system. A comparison of enhanced digital images with dental X-ray film. Dentomaxillofac Radiol 1996;25(4):202-6.

9. Nielsen LL, Hoernoe M, Wenzel A. Radiographic detection of cavitation in approximal surfaces of primary teeth using a digital storage phosphor system and conventional film, and the relationship between cavitation and radiographic lesion depth: an in vitro study. Int J Paediatr Dent 1996;6(3):16772 . tized radiographs were found. The $\mathrm{A}_{\mathrm{z}}$ values calculated for the radiographs did not exceed 0.91, while those obtained with subtraction images ranged from 0.98 to 0.99 . Our findings support the better accuracy of subtraction images for diagnosing subtle enamel demineralization.

\section{CONCLUSION}

It was possible to discriminate two radiographic modalities for detecting enamel demineralization. Digital images acquired with DenOptix ${ }^{\circledR}$ system represent the advances in the development of photostimulable phosphor plates and may be indicated as an alternative to conventional radiographs. On the other hand, radiographs taken with InSight ${ }^{\circledR}$ film are less expensive with no detriment to diagnostic accuracy. Finally, digital subtraction may show great promise in improving radiographic diagnosis of approximal enamel caries lesions.

10. Ohki M, Okano T, Nakamura T. Factors determining the diagnostic accuracy of digitized conventional intraoral radiographs. Dentomaxillofac Radiol 1994;23(2):77-82.

11. Price C, Ergül N. A comparison of a film-based and a direct digital dental radiographic system using a proximal caries model. Dentomaxillofac Radiol 1997;26(1):45-52.

12. Razmus TF. Caries, periodontal disease, and periapical changes. Dent Clin North Am 1994;38(1):13-31.

13. Reddy MS, Jeffcoat MK. Digital subtraction radiography. Dent Clin North Am 1993;37(4):553-65.

14. Svanaes DB, Moystad A, Risnes S, Larheim TA, Gröndahl HG. Intraoral storage phosphor radiography for approximal caries detection and effect of image magnification. Comparison with conventional radiography. Oral Surg Oral Med Oral Pathol Oral Radiol Endod 1996;82(1):94-100.

15. Syriopoulos K, Sanderink GCH, Velders XL, van der Stelt PF. Radiographic detection of approximal caries: a comparison of dental films and digital imaging systems. Dentomaxillofac Radiol 2000;29(5):312-8.

16. Wenzel A, Borg E, Hintze H, Gröndahl HG. Accuracy of caries diagnosis in digital images from charge-coupled device and storage phosphor systems: an in vitro study. Dentomaxillofac Radiol 1995;24(4):250-4.

17. Wenzel A, Pitts N, Verdonschot EH, Kalsbeek H. Developments in radiographic caries diagnosis. J Dent 1993;21(3):131-40.

18. White SC, Yoon DC. Comparative performance of digital and conventional images for detecting proximal surface caries. Dentomaxillofac Radiol 1997;26(1):32-8.

Received for publication on Sep 23, 2005 Sent for alterations on Jan 11, 2006 Accepted for publication on Mar 14, 2006 